\title{
Robbins, eterno Robbins
}

\section{Robbins forever}

\author{
Francisco Javier Torres Gómez ${ }^{1,2}$
}

Palabras clave: Robbins; patología; texto; estudiantes; médicos.

Keywords: Robbins; Pathology; Text; Students; Medical doctors.

Señor editor,

Quisiera comenzar la presente carta declarando la ausencia de conflicto de intereses que me pudieran vincular con la editorial Elsevier, de la que no he obtenido más beneficio que el mismo saber. Es por ello por lo que me siento libre para alabar el gran trabajo que se ha venido haciendo a lo largo de los años para que el conocido texto de patología comúnmente conocido como "Robbins" se adapte a los tiempos, incorporando los aspectos esenciales o fundamentales para entender de un modo sencillo y eficaz los factores moleculares, celulares y tisulares que subyacen a la génesis de la enfermedad.

Hasta ahora no desvelo ningún secreto. Los hechos avalan las aseveraciones previas. Como patólogo las refrendo. Pero si me he subido a este privilegiado atril, es para hablar como profesor con experiencia en la docencia de la asignatura de patología en las disciplinas de medicina, odontología y fisioterapia. La patología (anatomía patológica en España) es una asignatura tan importante, que resulta incongruente asistir a la pérdida de peso que la misma adquiere paulatinamente en los programas de formación de las distintas carreras sanitarias. La consecuencia directa de este hecho no es otra que un gran número de lagunas en la concepción de la patología y de los procesos que en ella desembocan, lo cual repercute en la comprensión de los informes patológicos por parte de distintos profesionales, con la consiguiente repercusión en el manejo posterior de los pacientes. Si el patólogo debe estudiar las distintas especialidades sanitarias, estas deberían hacer lo propio para lograr alcanzar un lenguaje común.
En mi opinión, todos los profesionales sanitarios deberían poseer y leer concienzudamente un libro de texto de patología, y en este sentido las distintas versiones existentes del texto de Robbins se postulan como la mejor opción. Mis alumnos siguen mi consejo y lo hacen. Al final de curso me lo agradecen. Sé, por experiencia, que en el futuro también lo harán.

Surge a continuación la duda acerca de cual de las distintas versiones y ediciones de este esencial texto debe adquirir un profesional para conseguir un mejor aprovechamiento de la lectura y comprensión. Es cierto que, independientemente de la versión lingüística que se elija, será la última edición la más completa, sin menosprecio de las anteriores, que a menor precio (debido a la devaluación) suelen cumplir con soltura su objetivo. Pero en los últimos años han aparecido en el mercado distintas variantes del texto original. Este último, titulado "Patología humana” (Kumar et al., 2018) en su décima edición, editado bajo la dirección de los doctores Kumar, Abbas y Aster, se antoja el más completo y está pensado para estudiantes de Medicina e incluso para médicos en ejercicio, patólogos incluidos y para profesores que, como un servidor, aman un texto que han comprado o adquirido una y otra vez desde que saliera a la luz la primera edición en 1971. Pero se trata de un texto extenso, detallado en exceso para estudiantes que quizás necesiten una visión más global. Precisamente pensando en los estudiantes, quiero destacar la existencia de compendios que, a modo de libro de bolsillo, pueden acompañar al estudiante allá a donde vayan (Mitchell et al., 2017). En cualquier caso, quisiera poner el acento en la obra de Klatt que, titulada "Robbins y Cotran,

(1) Servicio de Anatomía Patológica. Hospital de Alta Resolución de Utrera. Sevilla. Sevilla. España. (2) PSI Departamento de Citología e Histología normal y patológica. Universidad de Sevilla.

javier.torres@citadiag.com 
Atlas de Anatomía Patológica" (Klatt, 2016), hace hincapié en la imagen, tan importante para comprender esta asignatura. Es de agradecer la incorporación de nuevas herramientas que, bajo la denominación de Student Consult, permiten el acceso a material digitalizado de gran utilidad en la comprensión, en la docencia y en el intercambio de información, muy acorde con la era que se abre ante nosotros.

Sin desmerecer lo anteriormente expuesto, acaba de salir al mercado la última versión, resumida de nuestro libro fetiche. Se titula "Robbins, Patología Esencial" (Kumar et al., 2021) e incluye un acceso a la versión inglesa del texto y a las imágenes en ella contenida. Se trata, sin duda, de una excelente noticia para los estudiantes, una novedad editorial llevada a cabo por los infatigables doctores Kumar, Abbas, Aster y Deyrup que resume del modo más eficaz posible los contenidos mínimos que un sanitario en ciernes o en ejercicio debería conocer. El libro, que cuenta con un precio mucho más asequible, está organizado del mismo modo que siempre lo ha hecho, un paseo desde la patología general a la órgano-específica, pero eliminando datos especializados que exceden del objetivo de sentar unas bases "patológicas firmes" y que, sin embargo, son esenciales para quienes opten por la patología como un modo de vida. Se trata de un arma docente que animo a conocer, que animo a comprar y que animo a difundir. Como patólogo, como profesor, como antiguo estudiante, me encuentro en condiciones de afirmar que "Patología Esencial" es un tesoro por descubrir.

Cordialmente,

\section{Francisco Javier Torres Gómez}

Anatomopatólogo y citólogo

\section{Referencias}

Kumar, Abbas y Aster, editores (2018). Robbins. Patología Humana. Décima edición. Elsevier España. Barcelona.

Kumar, Abbas, Aster y Deyrup, editores (2021). Robbins. Patología Esencial. Elsevier España. Barcelona.

Klatt. Robbins \& Cotran (2016). Atlas de Anatomía Patológica. Tercera edición. Elsevier España. Barcelona.

Mitchell, Kumar, Abbas \& Aster (2017). Compendio de Robbins y Cotran. Patología Estructural y Funcional. Novena edición. Elsevier España. Barcelona. 